\title{
Social inequalities in health behaviors among Brazilian adults: National Health Survey, 2013
}

\author{
Marilisa Berti de Azevedo Barros ${ }^{1}$, Margareth Guimarães Lima ${ }^{1,4^{*}}$, Lhais de Paula Barbosa Medina', \\ Celia Landman Szwarcwald ${ }^{2}$ and Deborah Carvalho Malta ${ }^{3}$
}

\begin{abstract}
Background: Considering the high socioeconomic inequalities prevailing in Brazil and lifestyle as a strong determinant of morbidity and premature mortality, our purpose was to evaluate the degree of socioeconomic disparities in the prevalence of health behaviors among Brazilian adult population using data from the 2013 Brazilian National Health Survey.

Method: Based on a sample of 49,025 individuals aged 20 to 59 years, we estimated the prevalence of several health behaviors and a score of unhealthy behaviors according to gender, education, race/color and possession of private health insurance. The prevalence ratios adjusted by age and gender were estimated by means of multiple Poisson regression and the analyses took into account the sampling design.

Results: Significant social inequalities were identified in the Brazilian adults. Higher prevalence of current smoking, leisure-time physical inactivity, sedentary lifestyle, whole milk consumption and low ingestion of greens, vegetables, and fruits were observed among the less educated, in the non-white population, and among those without private health insurance. Higher prevalence of heavy episodic drinking was found in the non-white population, but no difference in the consumption of fatty meat was found according to skin color. Score of unhealthy behavior higher than 6 was more frequent in lower educational strata $(P R=3.74)$ in the non-white population $(P R=1.39)$ and among those without private health insurance $(P R=1.78)$. Compared to women, men had higher prevalence rates of smoking, hazardous alcohol consumption, and fatty meat consumption and lower consumption of greens, vegetables and fruits.

Conclusion: The results of the study emphasize the importance of monitoring social inequalities in health as part of national health policies and the urgent need to prioritize actions to promote healthy behaviors, especially among the most socially vulnerable segments of society.
\end{abstract}

Keywords: Health behavior, Social inequalities, Smoking, Alcohol, Leisure-time physical activity, Diet

\section{Background}

The surveillance of social inequalities in health is an essential task in all countries, but particularly important in countries with high rates of income inequality [1]. Social determinants shape the health profile of the population, the adoption of health-related behaviors, and the

\footnotetext{
* Correspondence: margarethglima@gmail.com

${ }^{1}$ State University of Campinas - UNICAMP, Campinas, Brazil

${ }^{4}$ Department of Public Health - UNICAMP - Tessália Vieira de Camargo, 126 -

Cidade Universitária Zeferino Vaz, 13083-887 Campinas, SP, Brazil

Full list of author information is available at the end of the article
}

organization and performance of healthcare systems. The literature on the social determinants of health has grown substantially in the last decades [2], highlighting the central role of health inequalities based on socioeconomic status, social class, gender, race/ethnicity and geography, among others $[3,4]$. Current evidence reveals these inequalities are substantial across different population groups in most health-related behaviors and outcomes [5-9].

The Commission on the Social Determinants of Health $(\mathrm{CSDH})$ has emphasized the need to incorporate 
the issue of health inequality into governments' political agendas $[6,7,10]$. The literature suggests that the magnitude of social inequalities varies with the type of health problem evaluated and with the socio-demographic subgroups undergoing comparison. Furthermore, multiple cultural and context variables influence, shape and interact with the effect of the socio-economic gradient on health [11]. In Brazil, analysis of health differences between segments with and without private health insurance provides an opportunity to assess the performance of the national health system - the Sistema Único de Saúde (SUS) - and to investigate the potential effect of national health policies on reducing health inequalities.

Today, a substantial part of the social differences in morbidity and mortality results from uneven patterns of health-related behaviors [12]. National and international literatures record the extent of social inequalities in the main risk factors for chronic diseases: smoking, physical inactivity/sedentary lifestyle, poor diet and harmful use of alcohol [9, 13-16]. In Australia, Ding et al. [14] observed reductions in the prevalence of harmful behaviors, from 2002 to 2012, coupled with an increase in inequalities across socioeconomic groups. In Spain, Bartoll et al. [15] observed improvements in the prevalence of healthy behaviors between 2001 and 2012, with varying degrees depending on the specific behavior, but confirmed that improvements were unequal across social groups.

Social inequalities in the prevalence of health-related behaviors may increase due to different temporal trends among social groups. Studies have shown that even when prevalence rates of harmful behaviors decline over time, disparities among social groups may increase [14, 17]. For example, despite Brazilian achievements in smoking cessation, the strongest decline in smoking prevalence occurred among individuals from higher socioeconomic status, which increased relative social disparities in tobaccorelated diseases and deaths [18]. This may result from the fact that higher levels of nicotine addiction have been found among the most excluded and marginalized social groups [13].

The impact of unhealthy behavior on diseases and mortality rates is widely recognized $[19,20]$. According to the World Health Organization (WHO) in 2012, about $6 \%$ of all deaths globally were attributable to alcohol consumption and $12 \%$ of deaths among men and $7 \%$ of deaths among women were attributable to smoking [20]. Insufficient physical activity accounts for 3.2 million deaths each year [20] and inadequate diets account for 11.3 million deaths and 241.4 million disability-adjusted life years [21].

Brazil has implemented several policies over the last decades that intended to reduce the prevalence of risk factors for chronic diseases. The Action Plan for Tackling
Non Communicable Diseases (NCDs), launched by the Brazilian Ministry of Health, defines priorities for interventions and resources to combat chronic diseases and their risk factors. Furthermore, this document recognizes the importance of equity in the government's agenda, including Strategy 7, which explicitly targets monitoring of social inequalities related to risk factors, diseases, mortality, and access to comprehensive care among people with non-communicable diseases [22].

Considering the magnitude of income disparities in the country, the prevailing social differences in the national morbi-mortality rates and the impact of health related behaviors in the incidence of diseases, disabilities and early deaths, this study aimed at assessing the degree of social related inequalities in the prevalence of health behaviors of the Brazilian population by gender, educational level, self-reported skin color and possession of private health insurance in 2013.

\section{Methods}

This is a cross-sectional population-based study, which used data from the National Health Survey (Pesquisa Nacional de Saúde - PNS), conducted by the Brazilian Institute of Geography and Statistics (IBGE) in partnership with the Ministry of Health. PNS is the most complete health survey ever conducted in Brazil, including questions on sociodemographic characteristics, health status, health behaviors and healthcare utilization, among others. The PNS data were collected in 2013 and 2014 using a probability sample taken in three stages. In the first stage, the primary sampling units (PSU) were composed of one or more census tracts and were selected by means of simple random sampling. In the second stage, 10 to 14 households were selected from each PSU. Finally, in the third stage, one person aged 18 years or over was selected from each household.

Interviews were pre-scheduled and data recorded on handheld computers (Personal Digital Assistants-PDAs). The PNS used three questionnaires: one referring to household characteristics, another with information about all residents, and the third soliciting information from the selected individual.

From the 64,348 households covered by the PNS, 60,202 people aged 18 years or more were interviewed, with losses totaling $20.8 \%$ and a non-response rate of $8.1 \%$. Information from 49,025 individuals aged 18-59 were analyzed in this study.

Dependent variables were: current smoking (yes, no); heavy episodic drinking - HED (consumption of four or more alcoholic drinks for women and five or more for men in a single occasion during the last 30 days); being inactive in leisure time (with active individuals defined as those who practice at least 150 minutes of mild/moderate or 75 minutes of vigorous physical activity a week 
and insufficiently active those who practice physical activity but do not reach 150 weekly minutes); sedentary lifestyle ( 5 or more hours per day watching TV); low consumption of vegetables, greens and fruits $(<5$ times a week); ingestion of meat with excess fat (yes, no); ingestion of whole milk (yes, no). An unhealthy behavior index was developed by adding up the following points, based on the type, frequency and degree of unhealthy behaviors: 2 points for current smoking; 2 for HED; 1 or 2 points for insufficient physical activity or physical inactivity, respectively; 1 for watching TV for 5 hours or more; 1 or 2 points for consumption of vegetables, greens and fruits 2 to 4 times a week or less than twice a week, respectively; 1 point each for consumption of meat with excess fat and whole milk. The total score ranged from 0 (best) to 11 (worst) and, based on its distribution, was dichotomized into low ( $<7$ points) or high ( 7 or more). Smoking and HED received 2 points each in order to avoid more under-representation of these behaviors in the combined score.

The independent variables were: gender (male and female); schooling level (college education complete, high school complete or college incomplete, elementary education complete or high school incomplete, illiterate or elementary education incomplete); skin color: white and non-white (including brown or black); and possession of private health insurance (yes, no).

Data analysis included calculation of unadjusted prevalence ratios (PR) and $95 \%$ confidence intervals (CI) for independent variables of each health-related behaviors. The differences were tested using the chi-square test. Sex and age adjusted prevalence ratios were estimated using multiple Poisson regression. Analyses were performed using the statistical software STATA 14.0 and accounted for the sampling complex design and unequal probabilities of selection.

The National Commission of Ethics in Research (CONEP) approved the PNS project on June 26, 2013 (Regulation number 328.159). All respondents have agreed to take part in the research and signed a free and informed consent form.

\section{Results}

We analyzed the data of 49,025 individuals of which 47.9 \% (95 \% CI: 47.1-48.7) were male. The average age of the population was 37 years (95 \% CI: 36.8-37.2). A total of $31.9 \%$ of the population had incomplete elementary school or no education, while $13.4 \%$ had completed college. The individuals who declared themselves brown and black totaled $53.3 \%$; $70.1 \%$ of the respondents did not have private health insurance (Table 1).

Analyzing health-related behaviors according to gender (Table 2), it can be seen that men had higher reporting of current smoking $(P R=1.70)$, heavy episodic drinking $(P R=3.01)$, low consumption $(<5$ times a week $)$ of fruits, greens and vegetables $(P R=1.12)$, and high consumption of meat with excess fat $(P R=1.63)$ and of whole milk $(P R=1.03)$ when compared to women. Women had higher prevalence of being physically inactive in leisure time $(P R=0.85)$ and having a sedentary lifestyle $(P R=0.79)$ than men. The prevalence of having

Table 1 Sample characteristics of Brazilian adult population (18 to 59 years of age). PNS 2013

\begin{tabular}{|c|c|c|}
\hline \multirow[b]{2}{*}{ Variables } & \multicolumn{2}{|l|}{ Total } \\
\hline & Number & Percent \\
\hline \multicolumn{3}{|l|}{ Gender } \\
\hline Male & 21,365 & 47.9 \\
\hline Female & 27,660 & 52.1 \\
\hline Total & 49,025 & 100.0 \\
\hline \multicolumn{3}{|l|}{ Age } \\
\hline 18 to 29 & 14,321 & 31.8 \\
\hline 30 to 39 & 14,269 & 26.4 \\
\hline 40 to 49 & 11,405 & 22.0 \\
\hline 50 to 59 & 9,030 & 19.8 \\
\hline \multicolumn{3}{|l|}{ Skin color } \\
\hline White & 18,792 & 46.7 \\
\hline Non-white (Black or brown) & 29,442 & 53.3 \\
\hline \multicolumn{3}{|l|}{ Schooling } \\
\hline College education complete & 6,672 & 13.4 \\
\hline High school complete or college incomplete & 17,739 & 37.4 \\
\hline $\begin{array}{l}\text { Elementary education complete or high school } \\
\text { incomplete }\end{array}$ & 8,269 & 17.2 \\
\hline Illiterate or elementary education incomplete & 16,345 & 31.9 \\
\hline \multicolumn{3}{|l|}{ Health insurance } \\
\hline With private health insurance & 13,025 & 29.9 \\
\hline Without private health insurance & 36,000 & 70.1 \\
\hline \multicolumn{3}{|l|}{ Health behavior } \\
\hline Current smoking & 7,325 & 15.2 \\
\hline Heavy episodic drinking & 7,629 & 15.7 \\
\hline Inactive during leisure time & 33,982 & 67,5 \\
\hline Sedentary lifestyle & 6,395 & 12.6 \\
\hline $\begin{array}{l}\text { Consumption of fruits, vegetables and greens } \\
\text { less than } 5 \text { times a week }\end{array}$ & 38,337 & 76.7 \\
\hline Consumption of meat with excess fat & 17,963 & 39.1 \\
\hline Consumption of whole milk & 30,314 & 61.1 \\
\hline \multicolumn{3}{|l|}{ Unhealthy behaviors score } \\
\hline 0 to 1 & 3,436 & 7.6 \\
\hline 2 to 3 & 12,453 & 26.1 \\
\hline 4 to 6 & 26,811 & 53.3 \\
\hline 7 or more & 6,325 & 13.0 \\
\hline
\end{tabular}


Table 2 Prevalence and prevalence ratios of unhealthy behaviors according to gender in the adult Brazilian population (18 to 59 years of age). PNS 2013

\begin{tabular}{|c|c|c|c|}
\hline \multirow[t]{2}{*}{ Health Behaviors } & \multicolumn{2}{|l|}{ Prevalence (\%) } & \multirow[t]{2}{*}{$\mathrm{PR}^{*}$ adjusted by age } \\
\hline & Female $n=27,660$ & Male $n=21,365$ & \\
\hline \multicolumn{4}{|l|}{ Smoking } \\
\hline Current smoking & 11.4 & 19.3 & $1.70(1.57-1.83)$ \\
\hline \multicolumn{4}{|l|}{ Alcoholic beverage consumption } \\
\hline Heavy episodic drinking & 7.9 & 24.3 & $3.01(2.83-3.33)$ \\
\hline \multicolumn{4}{|l|}{ Physical activity/sedentarism } \\
\hline Inactive during leisure time & 72.9 & 61.6 & $0.85(0.83-0.87)$ \\
\hline Sedentary lifestyle & 14.0 & 11.1 & $0.79(0.73-0.86)$ \\
\hline \multicolumn{4}{|l|}{ Diet } \\
\hline $\begin{array}{l}\text { Consumption of fruits, vegetables and greens } \\
\text { less than } 5 \text { times a week }\end{array}$ & 72.3 & 81.5 & $1.12(1.11-1.15)$ \\
\hline Consumption of meat with excess fat & 30,0 & 49.0 & $1.63(1.57-1.70)$ \\
\hline Consumption of whole milk & 60,3 & 61.9 & $1.03(1.0-1.05)$ \\
\hline \multicolumn{4}{|l|}{ Unhealthy behaviors score } \\
\hline 7 or more & 8.2 & 18.2 & $2.23(2.04-2.43)$ \\
\hline
\end{tabular}

*Category of reference: female

an unhealthy behaviors score of seven or more was higher among men versus women $(P R=2.23)$.

Table 3 shows behavioral prevalence rates by educational level. Respondents with less education had higher prevalence of current smoking, leisure time physical inactivity, sedentary lifestyle, and consumption of meat with excess fat and whole milk than those with more formal education.
Also, those with less education had lower consumption of greens, vegetables and fruits and higher than those with more education. The prevalence of the unhealthy behavior score of seven or more increased with lower educational levels; the PR (3.74) was significantly higher among those illiterate or with incomplete elementary education as compared to those who had completed college.

Table 3 Prevalence and prevalence ratios of unhealthy behaviors according to schooling in the adult Brazilian population (18 to 59 years of age). PNS 2013

\begin{tabular}{|c|c|c|c|c|c|c|c|}
\hline \multirow[t]{2}{*}{ Health behaviors } & \multicolumn{4}{|c|}{ Prevalence (\%) } & \multicolumn{3}{|c|}{$\mathrm{PR}^{*}$ adjusted by gender and age } \\
\hline & (1) & $(2)$ & (3) & (4) & (2) & (3) & (4) \\
\hline \multicolumn{8}{|l|}{ Smoking } \\
\hline Current smoking & 8.4 & 10.3 & 17.1 & 22.8 & $1.30(1.10-1.56)$ & $2.14(1.81-2.55)$ & $2.59(2.21-3.03)$ \\
\hline \multicolumn{8}{|l|}{ Alcoholic beverage consumption } \\
\hline Heavy episodic drinking & 15.7 & 15.9 & 16.9 & 14.9 & $0.93(0.81-1.01)$ & $0.99(0.81-1.02)$ & $1.00(0.89-1.13)$ \\
\hline \multicolumn{8}{|l|}{ Physical activity/sedentarism } \\
\hline Inactive during leisure time & 49.0 & 61.9 & 68.5 & 81.4 & $1.30(1.23-1.36)$ & $1.43(1.36-1.50)$ & $1.63(1.55-1.70)$ \\
\hline Sedentary lifestyle & 8.1 & 11.7 & 14.0 & 14.6 & $1.37(1.15-1.62)$ & $1.66(1.38-2.02)$ & $1.85(1.54-2.20)$ \\
\hline \multicolumn{8}{|l|}{ Diet } \\
\hline $\begin{array}{l}\text { Consumption of fruits, vegetables } \\
\text { and greens less than } 5 \text { times a week }\end{array}$ & 61.3 & 74.8 & 80.2 & 83.4 & $1.19(1.14-1.23)$ & $1.27(1.22-1.33)$ & $1.37(1.32-1.42)$ \\
\hline Consumption of meat with excess fat & 28.3 & 36.3 & 43.8 & 44.5 & $1.25(1.15-1.36)$ & $1.51(1.39-1.65)$ & $1.59(1.47-1.75)$ \\
\hline Consumption of whole milk & 49.3 & 63.6 & 64.6 & 61.2 & $1.27(1.20-1.34)$ & $1.29(1.22-1.37)$ & $1.25(1.20-1.34)$ \\
\hline \multicolumn{8}{|l|}{ Unhealthy behaviors score } \\
\hline 7 or more & 5.2 & 9.5 & 14.9 & 19.3 & $1.82(1.49-2.46)$ & $2.86(2.31-3.56)$ & $3.74(3.10-4.51)$ \\
\hline
\end{tabular}

(1) College education complete

(2) High school complete or college incomplete

(3) Elementary education complete or high school incomplete

(4) Illiterate or elementary education incomplete

*Category of reference: college education complete 
Table 4 shows that individuals who declared themselves non-white (black or brown) had higher prevalence of current smoking $(P R=1.25)$, heavy episodic drinking $(P R=1.11)$, inactivity in leisure time $(P R=1.09)$, sedentary lifestyle $(P R=1.27)$, and low consumption of vegetables and fruits $(R P=1.15)$ than white individuals. The prevalence of the unhealthy behavior score of seven or more was $39 \%$ higher in the non-white (vs. white) population.

Table 5 shows prevalence rates for people with and without private health insurance. Among those without private health insurance there were higher prevalence rates of current smoking $(P R=1.73)$, leisure time inactivity $(P R=1.33)$, sedentary lifestyle $(P R=1.49)$, low consumption of greens, vegetables and fruits $(R P=1.23)$, and high consumption of meat with excess fat $(P R=$ 1.29) and whole milk $(P R=1.12)$ than those with private insurance. The unhealthy behavior score was $78 \%$ higher in the group without private health insurance (vs. the group with private insurance).

\section{Discussion}

The results of this study reveal significant social inequalities in the prevalence of health behaviors in Brazil. These inequalities were expressed by differentials in the prevalence of harmful behaviors by gender, educational level, race/skin color and possession of private health insurance, with the magnitude of the inequality differing by type of behavior and stratifying variable.

Smoking prevalence was higher among males, among those with lower educational levels, in non-white individuals and in the population without private health insurance.
This study identified a $15.2 \%$ smoking prevalence: $19.3 \%$ among men and $11.4 \%$ in women. The Global Adult Tobacco Survey (GATS) revealed that the use of any tobacco product ranged from $21.6 \%$ in Brazil, to $60.2 \%$ in Russia, in the male population, and from $1.4 \%$ in Vietnam to $42.4 \%$ in Poland among women [23]. Globally, smoking prevalence is 4.4 times higher in men. Lower gender disparities are reported in the regions of the Americas and Europe [23] and higher inequality is reported in China, India, Japan and in the Philippines [24].

Higher smoking prevalence tends to occur among populations from lower socioeconomic backgrounds [25]. Our results are consistent with research conducted in Brazil and other countries, revealing socioeconomic inequalities based on schooling and race: smoking prevalence rates among individuals with low schooling [26, 27] and non-whites [28] were more than twice that of their more educated and white counterparts. Krieger et al. (2013), in the United States, also found a worse situation regarding health behaviors in the black population, detecting $27 \%$ higher prevalence of smoking among blacks (versus whites), which was similar to our results $(P R=1.25)$ [28].

Smoking prevalence has declined considerably in Brazil over the past 20 years. This decline was observed across several sociodemographic groups and in different regions of the country. For instance, smoking prevalence among people aged 18 or more declined from $34.8 \%$ in 1989 [29] to $18.1 \%$ in 2008 [30]. Prevalence rates are still lower in the capitals of Brazilian states [27], totaling $11 \%$ of the population aged 18-64 years. However, inequalities persist indicating the need to improve health services to support

Table 4 Prevalence and prevalence ratios of unhealthy behaviors according to skin color in the adult Brazilian population (18 to 59 years of age). PNS 2013

\begin{tabular}{|c|c|c|c|}
\hline \multirow[t]{2}{*}{ Health Behaviors } & \multicolumn{2}{|c|}{ Prevalence (\%) } & \multirow{2}{*}{$\begin{array}{l}\mathrm{PR}^{*} \text { adjusted by } \\
\text { gender and age }\end{array}$} \\
\hline & White & Non-white & \\
\hline \multicolumn{4}{|l|}{ Smoking } \\
\hline Current smoking & 13.6 & 16.5 & $1.25(1.15-1.35)$ \\
\hline \multicolumn{4}{|l|}{ Alcoholic beverage consumption } \\
\hline Heavy episodic drinking & 14.7 & 16.7 & $1.11(1.04-1.20)$ \\
\hline \multicolumn{4}{|l|}{ Physical activity/sedentarism } \\
\hline Inactive during leisure time & 65,0 & 69,9 & $1.09(1.06-1.11)$ \\
\hline Sedentary lifestyle & 10.9 & 14.0 & $1.27(1.16-1.40)$ \\
\hline \multicolumn{4}{|l|}{ Diet } \\
\hline $\begin{array}{l}\text { Consumption of fruits, vegetables } \\
\text { and greens less than } 5 \text { times a week }\end{array}$ & 70.7 & 81.9 & $1.15(1.13-1.17)$ \\
\hline Consumption of meat with excess fat & 38.2 & 40.1 & $1.05(0.99-1.09)$ \\
\hline Consumption of whole milk & 60,1 & 62.1 & $1.03(1.00-1.06)$ \\
\hline \multicolumn{4}{|l|}{ Unhealthy behaviors score } \\
\hline 7 or more & 10.8 & 14.9 & $1.39(1.27-1.52)$ \\
\hline
\end{tabular}

*Category of reference: white 
Table 5 Prevalence and prevalence ratios of unhealthy behaviors according to private health insurance in the adult Brazilian population (18 to 59 years of age). PNS 2013

\begin{tabular}{|c|c|c|c|}
\hline \multirow[b]{2}{*}{ Health Behaviors } & \multicolumn{2}{|l|}{ Prevalence (\%) } & \multirow{2}{*}{$\begin{array}{l}\mathrm{PR}^{*} \text { adjusted by } \\
\text { gender and age }\end{array}$} \\
\hline & With private health insurance & Without private health insurance & \\
\hline \multicolumn{4}{|l|}{ Smoking } \\
\hline Current smoking & 10.3 & 17.3 & $1.73(1.56-1.91)$ \\
\hline \multicolumn{4}{|l|}{ Alcoholic beverage consumption } \\
\hline Heavy episodic drinking & 15.9 & 15.6 & $0.95(0.88-1.03)$ \\
\hline \multicolumn{4}{|l|}{ Physical activity/sedentarism } \\
\hline Inactive during leisure time & 55.4 & 72.7 & $1.33(1.29-1.37)$ \\
\hline Sedentary lifestyle & 9.3 & 13.9 & $1.49(1.35-1.65)$ \\
\hline \multicolumn{4}{|l|}{ Diet } \\
\hline $\begin{array}{l}\text { Consumption of fruits, vegetables } \\
\text { and greens less than } 5 \text { times a week }\end{array}$ & 65.8 & 81.3 & $1.23(1.20-1.26)$ \\
\hline Consumption of meat with excess fat & 32.5 & 42.0 & $1.29(1.22-1.35)$ \\
\hline Consumption of whole milk & 56.3 & 63.1 & $1.12(1.08-1.15)$ \\
\hline \multicolumn{4}{|l|}{ Unhealthy behaviors score } \\
\hline 7 or more & 8.1 & 15.1 & $1.78(1.65-1.93)$ \\
\hline
\end{tabular}

*Category of reference: with private health insurance

smoking cessation [31], especially for the population with low educational levels, precisely those assisted by the public health system.

Alcohol consumption is another behavior highly related to health. Harmful alcohol consumption is associated with a wide spectrum of diseases, mental disorders, and injuries, as well as social, economic and legal problems [32]. However, due to industry pressure and broad social acceptance, initiatives to control the commercialization and advertisement of alcoholic beverages are much more limited than those for tobacco. Today, in many countries including Brazil, alcoholic drinks are widely available, and they are the subject of broad advertising. These aspects are important when considering the need to reduce the unequal social distribution of the consequences of alcohol consumption.

In this study HED reached $15.7 \%$ of the Brazilian adult population aged 18 to 59 , with prevalence of $24.3 \%$ among men and $7.9 \%$ among women. These prevalence rates were somewhat lower than those obtained by the telephone surveys (VIGITEL) conducted with residents in Brazilian capitals aged 18 or more, $(16.4 \%$ prevalence of HED in 2013) [16].

Studies from Brazil and other countries found an increase in the rate of habitual and hazardous alcohol consumption in the last decade [31, 32], with a more dramatic increase in women [33]. Although alcohol consumption is increasing among females, the results of this study show that HED is 3 times higher in males, a finding that is consistent with the literature $[32,33]$. Although consumption continues to be higher among males than females, there is evidence indicating greater vulnerability of women to the harmful use of alcohol [32].

In this study, no differences were found in the prevalence of heavy episodic drinking by educational level or private health insurance. Other studies have detected a higher frequency of habitual alcohol ingestion in the group with high socioeconomic status (assessed by different variables) [32, 33]. As to HED, somewhat discrepant results have been found, although most studies $[16,20,34]$ indicate higher prevalence of HED in the segments of higher socioeconomic status. Higher hazardous consumption in the black population, as found in this study, has been reported in some studies, and has been in part attributed to racial segregation contexts $[35,36]$.

In this research, findings regarding physical activity point to high rates of inactivity: $67.5 \%$ of the Brazilian adult population is inactive in their leisure time. In the population aged 18 years or more and resident in Brazilian capitals, the prevalence of physical inactivity in leisure time was $64.7 \%$ in 2014 [22] and there is a decrease trend in this non-practice, especially among young people and those with more education [37]. In the United States, according to NHIS data from 2012, $30 \%$ of the adult population is considered inactive and $20 \%$ insufficiently active [38]. Brazilian women have higher prevalence of inactivity or insufficient physical activity during leisure time than men, which is consistent with the literature [22, 39].

There was significant educational inequality in the practice of leisure-time physical activity in Brazil. Respondents with less education are $63 \%$ more likely to 
be inactive in leisure time than those with more education. These findings are consistent with those observed in other countries [22, 40,41]. The inequality between brown/black and white individuals was small with rates slightly lower for non-whites. Research conducted in the USA also found lower rates of leisure-time physical inactivity among black and other minority groups. However, in one study the difference became less evident after adjustments for social class [42, 43]. Individuals without health insurance (users of the public health system) also had a higher prevalence of leisure-time physical inactivity when compared with those who have private insurance, stressing the need for maintenance of strategies to raise physical activity levels among users of public health systems.

The time spent each day watching TV, used as an indicator of sedentarism, has been investigated in relation to its negative effect on health $[44,45]$. In this study, women showed higher prevalence than men of watching TV for 5 hours or more, which differs from the results obtained for adult residents in Brazilian capitals, where no difference was found between genders in 2013 or in 2014, for 3 hours or more of TV time [27, 46].

Sedentary lifestyle (watching TV 5 hours or more a day) proved to be socially inequitable. Higher prevalence rates were found in the lower educational stratum (86\% higher), in the non-white population (27\% higher) and among individuals without private health insurance (49\% higher) [37]. Mielke et al. studying the population aged 18 years and over, in a city in southern Brazil, and Clark et al (2014), with seniors in Australia, also found higher TV time in individuals with less education [37, 47].

To reduce inequalities, such as the ones identified in our study, Brazil needs to maintain and strengthen the existing policies aimed at fostering healthy behaviors in the context of primary care [48]. One of the actions of the plan for tackling chronic diseases in Brazil is the Health Academy program, which are public spaces for the practice of leisure physical activity and healthy lifestyles [22, 48].

Gender inequalities were found in the behaviors related to food. Lower prevalence of consumption of leaf vegetables, raw vegetables, and fruits was observed in men. A similar profile was detected in 2014 in the 26 Brazilian capitals and federal district [27]. A study conducted in the United States also reported lower consumption of fruits and vegetables among men [49], as well as in a research conducted in the United Kingdom, which found an average daily consumption of fruits and vegetables of $581 \mathrm{~g}$ for women and $472 \mathrm{~g}$ for men [50]. Moreover, a higher prevalence of consumption of meat with higher content of fat and whole milk was observed among men. A study conducted in Germany showed a higher consumption of animal fats among men, with average daily consumption of $19 \mathrm{~g}$ compared to $13 \mathrm{~g}$ for women [51]. A meta-analysis published in 2011 reported that the consumption of low fat milk was associated with a $16 \%$ reduction in the risk of increasing blood pressure [52].

Our results revealed significant social inequalities in the quality of the food consumed by different groups of the population. Insufficient consumption of leaf vegetables, raw vegetables and fruits were significantly higher in the strata of lower education, in the non-white population, and among those without health insurance. These findings are consistent with other studies conducted in Brazil [46, 53, 54] and other countries. A study conducted in Australia identified higher consumption of fibers among adults with a better educational level [55]. Also, a systematic review by Darmon and Drewnowski documented an association between higher socioeconomic status and higher consumption of whole grains in most of the reviewed studies. Socially advantaged groups consumed not only larger amount of fruits and vegetables but also a greater variety of these foods [56]. A study conducted in five European countries found higher prevalence of obesity-related behaviors in neighborhoods of lower socioeconomic status [57]. As for those with health insurance, results from another Brazilian study corroborated the findings from our study regarding better food profile among individuals who had private health plan [18].

The consumption of meat with higher fat content was higher among people with lower education levels, in the non-white population, and in the stratum without a health plan. Vigitel data confirms these findings among men, but not among women [18]. However, studies conducted in Denmark, United States, Netherlands, and France observed increased consumption of lean meats, in the groups of high socioeconomic status [58-61].

Higher prevalence of consumption of milk with full-fat content was observed in the stratum of low education levels, in black and brown populations, and in individuals without a health insurance. A study conducted in the United States determined that the chance of buying low-fat milk was $50 \%$ to $58 \%$ lower among Latinos when compared to white communities and that the availability of skim milk or with $1 \%$ fat milk was lower in low-income communities [62].

In Brazil, many efforts have been made to improve the quality of the Brazilian diet. Among them, we should point out the review of the 2014 Brazilian Food Guide. This innovative guide categorizes food according to the degree of processing and emphasizes the importance of homemade meals and food-based in natura. In addition, the new Brazilian Food Guide supports policies and programs aimed at promoting health, food safety and nutrition [63]. It should also be said that the Brazilian government regulated food labels and signed agreements 
with the food industry to reduce the amount of trans fats and sodium in processed foods [22].

We need to consider some limitations of this study. Data on health behavior are self-reported; social desirability of response and recall bias could lead to underestimation of some unhealthy behaviors. Specifically regarding the consumption of alcohol, the PNS questionnaire only asks the number of drinks and does not take into account the amount of alcohol contained in each type of alcoholic beverage. Information on the beverage consumed would increase the accuracy of the amount of alcohol consumed. However, the PNS questionnaire is similar to that of Vigitel, the Brazilian telephone survey, and several studies using these indicators confirm their validity [63-65].

On the other hand, the study has advantages. Firstly, the survey is a population-based study representative of the non-institutionalized Brazilian population. The information generated in this study is important for its focus on social inequalities in health and in health behaviors, which is scarce in developing countries and in Latin America, especially considering associations with educational level and possession of private health insurance. The study also provides important information about health behaviors in the adult population that is critical for the control of non-transmissible chronic diseases.

The results of this study revealed that a higher frequency of harmful behaviors occurs in segments with low socioeconomic background and in the non-white population, which are groups that largely depend on the Brazilian public health system for their therapeutic and preventive health care needs. These findings emphasize the role of the public health system in promoting interventions to stimulate healthy behaviors among the less advantaged groups and consequently contribute to reducing social inequalities in health. The system needs to increase the investments in health promotion, besides providing adequate health care services, including qualified and accessible support for those who intend to control their tobacco and alcohol dependence and those who need to manage their excess weight. Several government initiatives can help to reduce those inequalities, including regulation of food industries and advertisement on food and alcoholic beverages, interventions to improve the quality of school meals, the creation of public spaces to encourage the practice of physical activities among others. The concentration of harmful behaviors in some groups of people points to the need for a comprehensive approach to tackle these issues.

\section{Conclusion}

Significant social inequalities in the Brazilian adult population, identified in this study, have profound implications for the country's morbimortality scenario in the near future. The decline that has been observed for many harmful behaviors, particularly the decline in smoking, while at the same time reducing the overall burden of early death and disabilities, can, however, be accompanied by persistent or even greater social inequalities in the incidence of these events. In general, the most socially vulnerable segments of the population have greater difficulty in adopting healthy practices. The monitoring of social disparities in terms of risk factors for NCDs, thus becomes crucial especially in Brazil, a society that continues to have one of the highest indices of income inequalities.

\section{Abbreviations}

$\mathrm{Cl}$ : Confidence interval; CONEP: National Commission of Ethics in Research; CSDH: Commission on the Social Determinants of Health; DALY: Disabilityadjusted life year; GATS: Global Adults Tobacco Survey; HED: Heavy episodic drinking; IBGE: Brazilian Institute of Geography and Statistics; NCD: Non communicable disease; NHIS: National Health Interview Survey; PDA: Personal digital assistance; PNS: National Health Survey; PR: Prevalence ratio; PSU: Primary sample unit; SUS: Public health system; VIGITEL: Telephonebased surveillance of risk and protective factors for chronic diseases; WHO: World Health Organization

\section{Acknowledgments}

The authors are grateful to the Ministry of Health of Brazil and the Secretary of Health Surveillance for supporting and financing the health survey (NHS 2013). MBA Barros, DC Malta, and CL Szwarcwald are supported by a Research Productivity Grant from CNPq. LPB Medina is supported by CAPES.

\section{Funding}

- Ministry of Health of Brazil - funded the National Health Research

- DCM and MBAB receive research productivity Exchange of the National Scientific and Technological Development Council (CNPq). LPB receives funding of CAPS.

\section{Authors' contributions}

BMBA proposed the study defining objectives and analysis, wrote the motivation and background for conducting this study and reviewed the literature. MDC performed the revision of the analysis and participated in the study design and reviewed the literature. SCL participated in the study design and reviewed the literature. LMG performed the data analysis and wrote part of the discussion and reviewed the literature, MLPB organized the structure of the manuscript and helped with part of the discussion and reviewed the literature. All authors contributed to multiple revisions of the article. All authors read and approved the final manuscript.

\section{Competing interests}

The authors declare that they have no competing interests.

\section{Consent for publication}

All authors read and approved the final manuscript.

\section{Ethics approval and consent to participate}

The National Commission of Ethics in Research (CONEP) approved the PNS project on June 26, 2013 (Regulation number 328.159). All respondents have agreed to take part in the research and signed a free informed consent form.

\section{Author details}

${ }^{1}$ State University of Campinas - UNICAMP, Campinas, Brazil. ${ }^{2}$ Foundation Institute Oswaldo Cruz - FIOCRUZ, Rio de Janeiro, Brazil. ${ }^{3}$ Federal University of Minas Gerais - UFMG, Belo Horizonte, Brazil. ${ }^{4}$ Department of Public Health - UNICAMP - Tessália Vieira de Camargo, 126 - Cidade Universitária Zeferino Vaz, 13083-887 Campinas, SP, Brazil.

Received: 3 May 2016 Accepted: 8 September 2016 Published online: 17 November 2016 


\section{References}

1. Instituto Brasileiro de Geografia e Estatística - IBGE 2015. Síntese de indicadores sociais: uma análise das condições de vida da população brasileira: 2015/IBGE, Coordenação de População e Indicadores Sociais. Rio de Janeiro: IBGE; 2015. p. 137.

2. Bouchard L, Albertini M, Batista R e, Montigny J. Research on health inequalities: a bibliometric analysis (1966-2014). Soc Sci Med. 2015;141:100-8.

3. Borrel C. Métodos utilizados no estudo das desigualdades sociais em Saúde In: Barata R, organizador, editors. Condições de vida e saúde. Rio de Janeiro: ABRASCO; 1997. p. 167-95.

4. Silva JB, Barros MBA. Epidemiologia e desigualdade: notas sobre a teoria e a história. Pan Am J Public Health. 2002;12(6):375-83.

5. Braveman PA, Cubbin C, Egerter S, Williams DR, Pamuk E. Socioeconomic disparities in health in th United States: what the patterns tell us. Am J Public Health. 2010;100 Suppl 1:186-96.

6. Comissão Nacional dos Determinantes Sociais em Saúde (CNDSS). As causas sociais das iniqüidades em saúde no Brasil/CNDSS. Rio de Janeiro: Editora Fiocruz; 2008

7. World Health Organization 2011. Diminuindo diferenças: a prática das políticas sobre determinantes sociais da saúde: documento de discussão da Conferência Mundial sobre Determinantes Sociais de Saúde. Rio de Janeiro, Brasil; 2011.

8. Mackenbach JP. The persistence of health inequalities in modern welfare states: The explanation of a paradox. Soc Sci Med. 2012;75:761-9.

9. Pampel FC, Krueger PM, Denney T. Socioeconomic disparities in health behaviors. Annu Rev Sociol. 2010;36:349-70.

10. Marmot M. WHO commission on social determinants of health. Closing the health gap in a generation: the work of the commission on social determinants of health and its recommendations. Glob Health Promot. 2009;Suppl 1:23-7.

11. Barros MBA, Francisco PM, Lima MG, Cesar CLG. Social inequalities in health among elderly. Cad Saude Publica. 2011;27 Suppl 2:S198-208.

12. Stringhini S, Sabia S, Shipley M, Brunner E, Nabi H, Kivimaki M, et al. Association of socioeconomic position with health behaviors and mortality. JAMA. 2010;303(12):1159-66.

13. Jarvis M, Wardle J. Social patterning of individual health behaviours: the case of cigarette smoking. In: Marmot M, Wilkinson RG, editors. Social determinants of health. Oxford: Oxford University Press; 1999. p. 240-55.

14. Ding D, Do A, Schmidt HM, Bauman AE. A widening gap? changes in multiple lifestyle risk behaviours by socioeconomic status in New South Wales, Australia, 2002-2012. PLoS One. 2015;10(8):1-13.

15. Bartoll X, Toffolutti V, Malmusi D, Palencia L, Borrel C, et al. Health and health behaviours before and during the Great Recession, overall and by socioeconomic status, using data from four cross-sectional health surveys in Spain (2001-2012). BMC Public Health. 2015;15:865.

16. Malta DC, Campos MO, Oliveira MM, Iser BPM, Bernal RT, Claro RM, Monteiro CA, Silva Jr JB, Reis AAC. Prevalência de fatores de risco e proteção para doenças crônicas não transmissíveis em adultos residentes em capitais brasileiras, 2013. Epidemiol, Serv Saúde, Brasília. 2015;24(3):373-87.

17. Maestre-Miquel C, Regidor E, Cuthill F, Martínez D. Desigualdad en la prevalencia de sedentarismo durante el tiempo libre en población adulta española según su nivel de educación. diferencias entre 2002 y 2012. Rev Esp Salud Publica. 2015:89:259-69.

18. Malta DC, Bernal RTI, Oliveira M. Tendências dos fatores de risco de doenças crônicas não transmissíveis, segundo a posse de planos de saúde, Brasil, 2008 a 2013. Cien Saude Colet. 2015;20(4):1005-16

19. World Health Organization. Global Action for the prevention and control of noncommunicable diseases 2013-2020. Geneva: World Health Organization; 2013. http://apps.who.int/iris/bitstream/10665/94384/1/9789241506236_eng. pdf. Accessed 27 April 2016.

20. Word Health Organization 2014a. Global Status Report on noncommunicable diseases 2014. World Health Organization, Geneva. http://apps.who.int/iris/bitstream/10665/148114/1/9789241564854_eng.pdf. Acessed 27 April 2016

21. Forouzanfar MH, Alexander L, Anderson HR, Bachman VF, Biryukov S, et al. Global, regional, and national comparative risk assessment of 79 behavioural, environmental and occupational, and metabolic risks or clusters of risks in 188 countries, 1990-2013: a systematic analysis for the Global Burden of Disease Study 2013. The Lancet. 2015;386(10010):2287-323.

22. Brasil, 2011. Ministério da Saúde. Secretaria de Vigilância em Saúde. Departamento de Análise de Situação de Saúde. Plano de ações estratégicas para o enfrentamento das doenças crônicas não transmissíveis (DCNT) no Brasil 2011-2022 - Brasília: Ministério da Saúde; 2011.
23. Giovino GA, Mirza SA, Samet JM, for The GATS Collaborative Group, et al. Tobacco use in 3 billion individuals from 16 countries: an analysis of nationally representative cross-sectional household surveys. Lancet. 2012;380:668-79.

24. Word Health Organization 2011. Gender, health, tobacco and equity. http:// www.who.int/tobacco/publications/gender/gender_tobacco_2010.pdf. Accessed 22 Aug 2016.

25. World Health Organization 2015. WHO report on the global epidemic, 2015: raising taxes on tobacco. World Health Organization, Luxembourg, 2015. http://apps.who.int/iris/bitstream/10665/178574/1/9789240694606_eng.pdf. Accessed 22 Aug 2016

26. Jamal A, Homa DM, O'Connor E, Babb SD, Caraballo RS, Singh T, Hu SS, King BA. Current cigarette smoking among adults - United States, 2005-2014. Cent Dis Control Prev: MMWR. 2015;64(44):1233-40.

27. Brasil, 2015. Ministério da Saúde. Secretaria de Vigilância em Saúde. Departamento de Vigilância de Doenças e Agravos não Transmissíveis e Promoção da Saúde. Vigitel Brasil 2014: vigilância de fatores de risco e proteção para doenças crônicas por inquérito telefônico/Ministério da Saúde, Secretaria de Vigilância em Saúde, Departamento de Vigilância de Doenças e Agravos não Transmissíveis e Promoção da Saúde. - Brasília: Ministério da Saúde; 2015.

28. Krieger N, Waterman PD, Kosheleva A, Chen J, Smith KW, Carney DR, Bennet GG, Williams DR, Thornhill G, Freeman ER. Racial discrimination and cardiovascular disease risk: My Body, My Story Study of 1005 US-Born black and white community health center participants (US). PLoS One. 2013:8(10):e77174

29. Monteiro CA, Cavalcante TM, Moura EC, Claro RM. Population-based evidence of a strong decline in the prevalence of smokers in Brazil (1989-2003). Bull World Health Organ. 2007;85(7):527-34

30. Brasil, 2009. Ministério do Planejamento e Gestão. Instituto Brasileiro de Geografia e Estatística - IBGE. Diretoria de Pesquisas. Coordenação de trabalho e rendimento. Rio de Janeiro: Pesquisa Nacional Por Amostra de Domicílios. Tabagismo; 2009

31. Szklo AS, Thrasher JF, Perez C, Figueiredo VC, Fong G, Almeida LM. Understanding the relationship between socioeconomic status, smoking cessation services provided by health system and smoking cessation behavior in Brazil. Cad Saude Publica. 2013:2(3):485-95.

32. World Health Organization 2014b. Global Status on alcohol and health. Geneva: World Health Organization; 2014. http://apps.who.int/iris/bitstream/ 10665/112736/1/9789240692763_eng.pdf. Acessed 27 April 2016.

33. Universidade Federal de São Paulo - UNIFESP. II Levantamento Nacional de Álcool e Drogas (LENAD) - 2012. Ronaldo Laranjeira (Supervisão) [et al.], São Paulo: Instituto Nacional de Ciência e Tecnologia para Políticas Públicas de Álcool e Outras Drogas (INPAD), UNIFESP. 2014.

34. Laranjeira R, Pinsky I, Sanches M, Zaleski M, Caetano R. Alcohol use patterns among Brazilian adults. Rev Bras Psiquiatr. 2010;32(3):231-41.

35. Moura EC, Malta DC. Consumo de bebidas alcoólicas na população adulta brasileira: características sociodemográficas e tendência. Rev Bras Epidemiol. 2011;14(1 Suppl):61-70.

36. Borrel LN, Kiefe Cl, Diez-Roux AV, Williams DR, Gordon-Laersen P. Rasila discrimination, racial/ethnic segregation and health behaviors in the CARDIA study. Ethn Health. 2013;18(3):227.

37. Mielke Gl, da Silva ICM, Owen N, Hallal PC. Brazilian Adults' Sedentary Behaviors by Life Domain: Population-Based Study. PLoS One. 2014;9(3): e91614.

38. Blackwell DL, Lucas JW, Clarke TC. Summary health statistics for U.S. adults: National Health Interview Survey, 2012. National Center for Health Statistics. Vital Health Stat. 2014. http://www.cdc.gov/nchs/data/series/sr_10/sr10_260. pdf. Accessed 23 Aug 2016.

39. Duca GFD, Nahas MV, Garcia LMT, Mota J, Hallal PC, Peres MA. Prevalence and sociodemographic correlates of all domains of physical activity in Brazilian adults. Prev Med. 2013;56(2):99-102.

40. Bauman A, Ma G, Cuevas F, Omar Z, Waqanivalu T, Phongsavan P, Keke K, Bhushan A. Cross-national comparisons of socioeconomic differences in the prevalence ofleisure-time and occupational physical activity, and active commuting in six Asia-Pacific countries. J Epidemiol Community Health 2011;65(1):35-43.

41. Beenackers MA, Giskes CBMK, Brug J, Kusnt AE, Burdorf A, Lenthe FJV. Socioeconomic inequalities in occupational, leisure-time, and transport related physical activity among European adults: A systematic review. Int J Behav Nutr Phys Act. 2012;9:116

42. August KJ, Sorkin DH. Racial/Ethnic disparities in exercise and dietary behaviors of middle-aged and older adults. J Gen Intern Med. 2010;26(3):245-50 
43. Marshall SJ, Jones DA, Ainsworth BE, Reis JP, Levy SS, Macera CA. Race/ ethnicity, social class, and leisure-time physical inactivity. Med Sci Sports Exerc. 2007;39(1):44-51.

44. Tremblay MS, Rachel CC, Saunders TJ, Healy GN, Owen N. Physiological and health implications of a sedentary lifestyle. Appli Physiol Nutr Metab. 2010;35:725-40

45. Koster A, Caserotti P, Patel KV, Berrigan D, Domelen DRV, Brychta RJ, Chen KY, Harris TB. Association of sedentary time with mortality independent of moderate to vigorous phyisical acitivity. PLoS One. 2012;7(6):e37696.

46. Brasil, 2014a. Ministério da Saúde. Secretaria de Vigilância em Saúde. Departamento de Vigilância de Doenças e Agravos não Transmissíveis e Promoção da Saúde. Vigitel Brasil 2013: vigilância de fatores de risco e proteção para doenças crônicas por inquérito telefônico/Ministério da Saúde, Secretaria de Vigilância em Saúde, Departamento de Vigilância de Doenças e Agravos não Transmissíveis e Promoção da Saúde. - Brasília: Ministério da Saúde; 2014.

47. Clark BK, Sugiyama T, Healy GN, Salmon J, Dunstan DW, Shaw JE, et al. Socio-demogaphic correlates of prolonged television viewing time in Australian men and women: The AusDiab study. J Phys Act Health. 2010;7:595-601.

48. Malta DC, Silva Jr JB. Polices to promote phyisical activity in Brazil. Lancet. 2012;21:195-6

49. Bazzano LA, He J, Ogden LG, Loria CM, Vupputuri S, et al. Fruit and vegetable intake and risk of cardiovascular disease in US adults: the first National health and nutrition examination survey epidemiologic follow-up study. Am J Clin Nutr. 2002;76:93-9.

50. Mackenbach JD, Brage S, Forouhi NG, Griffin SJ, Wareham NJ, Monsivais P. Does the importance of dietary costs for fruit and vegetable intake vary by socioeconomic position? Br J Nutr. 2015;114:1464-70.

51. Heuer T, Krems C, Moon K, Brombach C, Hoffmann I. Food consumption of adults in Germany: results of the German National Nutrition Survey II based on diet history interviews. Br J Nutr. 2015;113:1603-14.

52. Ralston RA, Lee JH, Truby H, Palermo CE, Walker KZ. A systematic review and meta-analysis of elevated blood pressure and consumption of dairy foods. J Hum Hypertens. 2012;26:3-13.

53. Levy-Costa RB, Sichieri R, Pontes NS, Monteiro CA. Disponibilidade domiciliar de alimentos no Brasil: distribuição e evolução (1974-2003). Rev. Saúde Pública. 2005;39(4):530-40.

54. Irala-EsteÂvez JD, Groth $M$, Johansson L, Oltersdorf U, Prättälä R, MartínezGonzález MA. A systematic review of socio-economic differences in food habits in Europe: consumption of fruit and vegetables. Eur J Clin Nutr. 2000;54:706-14.

55. Evans A, Booth H, Cashel K. Sociodemographic determinants of energy, fat and dietary fiber intake in Australian adults. Public Health Nutr. 1999;3(1):67-75.

56. Darmon N, Drewnowski A. Does social class predict diet quality? Am J Clin Nutr. 2008;87(5):1107-17.

57. Lakerveld J, Rebah MB, Mackenbach JD, Charreire H, Compernolle S, Glonti K, Bardos H, Rutter H, Bourdeaudhuij ID, Brug J, Oppert J. Obesity-related behaviours and BMI in five urban regions across Europe: sampling design and results from the SPOTLIGHT cross-sectional survey. BMJ Open. 2015;5:e008505

58. Groth MV, Fagt S, Brondsted L. Social determinants of dietary habits in Denmark. Eur J Clin Nutr. 2001;55:959-66.

59. Shimakawa T, Sorlie P, Carpenter MA, Dennis B, Tell GS, Watson R, et al. Dietary intake patterns and sociodemographic factors in the atherosclerosis risk in communities study. ARIC Study Investigators. Prev Med. 1994;23:769-80

60. Hulshof KF, Brussaard JH, Kruizinga AG, Telman J, Lowik MR. Socio-economic status, dietary intake and $10 \mathrm{y}$ trends: the dutch national food consumption survey. Eur J Clin Nutr. 2003;57:128-37.

61. Perrin AE, Simon C, Hedelin G, Arveiler D, Schaffer P, Schlienger JL. Ten-year trends of dietary intake in a middle-aged French population: relationship with educational level. Eur J Clin Nutr. 2002;56:393-401.

62. Rimkus L, Isgor Z, Ohri-Vachaspati P, Zenk SN, Powell LM, et al. Disparities in the availability and price of low-fat and higher-fat milk in US food stores by community characteristics. Acad Nutr Diet. 2015;115(12):2212-672.

63. Brasil, 2014b. Ministério da Saúde. Secretaria de Atenção à Saúde. Departamento de Atenção Básica. Guia alimentar para a população brasileira/ Ministério da Saúde, Secretaria de Atenção à Saúde, Departamento de Atenção Básica. - 2. ed. - Brasília : Ministério da Saúde, 2014.
64. Monteiro CA, Moura EC, Jaime PC, Claro RM. Validity of food and beverage intake data obtained by telephone survey. Rev Saude Publica. 2008;42(4):582-9.

65. Neves ACMD, Gonzaga LAA, Martens IBG, Moura EC. Validação de indicadores do consumo de alimentos e bebidas obtidos por inquérito telefônico em Belém, Pará, Brasil. Cad Saude Publica. 2008;26(12):2379-88.

\section{Submit your next manuscript to BioMed Central and we will help you at every step:}

- We accept pre-submission inquiries

- Our selector tool helps you to find the most relevant journal

- We provide round the clock customer support

- Convenient online submission

- Thorough peer review

- Inclusion in PubMed and all major indexing services

- Maximum visibility for your research

Submit your manuscript at www.biomedcentral.com/submit
C Biomed Central 